\title{
The Influence of Political Socialization among Educated Youth at Universiti Putra Malaysia
}

Mohd Mahadee Ismail, Nor Azlili Hassan, Mohd Sabri Md Nor, Mohd Izani Mohd Zain \& Ku Hasnita Ku Samsu

To Link this Article: http://dx.doi.org/10.6007/IJARBSS/v11-i12/11941

DOI:10.6007/IJARBSS/v11-i12/11941

Received: 09 October 2021, Revised: 11 November 2021, Accepted: 29 November 2021

Published Online: 17 December 2021

In-Text Citation: (Ismail et al., 2021)

To Cite this Article: Ismail, M. M., Hassan, N. A., Nor, M. S. M., Zain, M. I. M., \& Samsu, K. H. K. (2021). The Influence of Political Socialization among Educated Youth at Universiti Putra Malaysia. International Journal of Academic Research in Business and Social Sciences, 11(12), 2142-2159.

Copyright: (c) 2021 The Author(s)

Published by Human Resource Management Academic Research Society (www.hrmars.com)

This article is published under the Creative Commons Attribution (CC BY 4.0) license. Anyone may reproduce, distribute, translate and create derivative works of this article (for both commercial and non0-commercial purposes), subject to full attribution to the original publication and authors. The full terms of this license may be seen

at: http://creativecommons.org/licences/by/4.0/legalcode

Vol. 11, No. 12, 2021, Pg. 2142- 2159

Full Terms \& Conditions of access and use can be found at http://hrmars.com/index.php/pages/detail/publication-ethics 


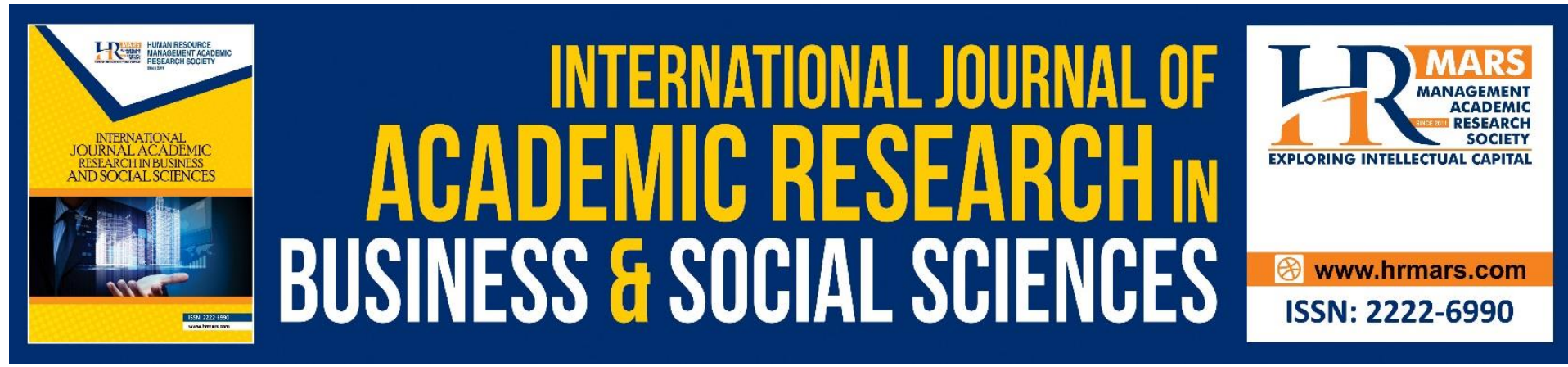

\title{
The Influence of Political Socialization among Educated Youth at Universiti Putra Malaysia
}

\author{
Mohd Mahadee Ismail ${ }^{1}$, Nor Azlili Hassan², Mohd Sabri Md \\ Nor ${ }^{1}$, Mohd Izani Mohd Zain ${ }^{1} \&$ Ku Hasnita Ku Samsu ${ }^{1}$ \\ ${ }^{1}$ Faculty of Human Ecology, Universiti Putra Malaysia, 43400 Serdang, Selangor, Malaysia, \\ ${ }^{2}$ Faculty of Creative Industries, Universiti Tunku Abdul Rahman, 43000 Sg Long Kajang, \\ Selangor, Malaysia \\ Email: mahadee@upm.edu.my
}

\begin{abstract}
This article discusses the influence of political socialization among educated youths in Malaysia, with special focus given to Universiti Putra Malaysia (UPM) students. The political learning process of youth groups is essential to be refined from time to time, especially in political socialization everyday defined until they reach a stage of maturity in their life. Many factors and agents are involved in the process of political socialization of an individual. Therefore, this article focuses on the factors and agents of political socialization that influence the learning process of political affairs among UPM students. This study used a quantitative approach with survey techniques using a self-administered questionnaire involving 431 educated Malay and Chinese youth for comparison in studying the influence of political socialization. This study showed that there are different variations on the influence of political socialization among Malay and Chinese youth. Each agent has its role in influencing the political socialization of the youth groups being studied. Ironically, the learning process about the political affairs of these educated youths is significantly influenced by educational and government factors and the family and peer group factors that have a strong influence, particularly in their literacy formation and political awareness.
\end{abstract}

Keywords: Political Socialization, Political Literacy, Educated Youth, UPM and Malaysia.

\section{Introduction}

Political socialization has had a significant influence on an individual's life since early childhood, adolescence, youth, and adulthood. Every individual will face the influence of political socialization, be it consciously or unconsciously, directly or indirectly, or voluntarily or involuntarily. Every experience that has been gone through the younger generation will be the catalyst to determine and shape the future pattern of the country. As the nation's future leaders, these youth play a crucial role in shaping Malaysia (Ismail et al., 2021). The development of the younger generation is the critical measure of a country. On the other hand, if these groups are not established, the defendant's future may be at risk. It's no surprise, then, that the focus of any youth development activity or programme revolves around youth groups aged 18 to 25 , especially in Malaysia's diverse society. Humans 
experiencing an acute psychosocial development complex at that age have a strong aversion to new things, a drive to explore the nature of existence, and a desire to push the boundaries of social rules and try something new (Ismail et al., 2021).

Political socialization involves the process of continuous learning about political behavior, the political culture of a society, the political system of a country, including matters and affairs about government and administration, or learning about political life (Hyman, 1959; Almond \& Coleman, 1960; Greenstein, 1960; Sigel, 1970 \& Easton, 1968). Merelman (1969) describes political socialization as the process by which people form long-lasting attitudes regarding politics in general and their political system in particular. People learn in many informal ways throughout life, often through encounters with parents, relatives, friends, neighbours, colleagues, and other people (Neundorf \& Smets, 2017). In addition, it is claimed that young people are not yet set in political ways and are thus influenced more easily by external circumstances. Although the early socialisation experiences of many youths are not agreed upon, they are nonetheless persistent (Neundorf \& Smets, 2017).

Thus, this paper discusses the influence of political socialization among youths in Malaysia, with a special focus on the students pursuing their studies at Universiti Putra Malaysia (UPM). These youths are the future pillars and backbone of the country who will shape, trigger and move the national development. This paper focuses on the factors and agents of political socialization that influence the learning process of political affairs among UPM students. Which factors and agents influence this educated young person most effectively in their everyday defined? The study took a sample of the educated Malay and Chinese youth only as a comparison. The results of this study can describe how each of the socialization agents brings political influence to the youth groups being studied as well as explain the dynamics of Malaysian society.

\section{Literature on Political Socialization Concept}

The theory of political socialization was put forward by Hyman (1959) through his book entitled Political Socialization. Later this theory was developed by some leading scholars such as (Pye, 1959; Greenstein, 1960; Hess and Easton, 1960; Almond and Coleman, 1960; Sigel, 1970). Hyman (1959) has proposed that if an individual wants to achieve stability in a political system, they must learn their political behavior well and continuously start at the early stage. Otherwise, political stability is difficult to achieve, and there is likely to be chaos in the country. Based on the argument, it can generally be said that political socialization focuses on the process of learning about political behavior (Hyman, 1959; Greenstein, 1960; Sigel, 1970), political culture (Almond \& Coleman, 1960), and political systems (Easton, 1968), including matters and affairs involving government and administration, or learning about political life in a country.

Socialization is a process of learning through experience and what is learned (Rush \& Althoff, 1971). The general definition of political socialization is "the process of induction into a political system" (Marshall, 1996, p. 400). The definition accepted by most scholars has been put forward by Sigel (1970), who defines political socialization as "the process by which people learn to adopt the norms, values, attitudes, and behaviors accepted and practiced by the ongoing (political) system" (McLeod, 2000, p. 45). According to Roberts (1971), political socialization is a learning process that exposes an individual to the orientation, beliefs, 
feelings and components of government values as well as political life, which is a form of orientation that encompasses the concepts of governance, democracy and political responsibility. What they learn and go through will be decisive to the political pattern and orientation in which they respond to the political scenario they will face based on what they have learned.

Ironically, political socialization focuses on citizenship development among the younger generation (McLeod, 2000), fostering political awareness, instilling a sense of loyalty to the state, as well as a high spirit of patriotism (Fairbrother, 2002; Langton, 1969; Merelman, 1972). More importantly, political socialization becomes a holistic mechanism in the development of political life, where the young generation in a country learns political affairs through various agents in society such as family, education, mass media and peer groups especially in the formation of norms, values, political beliefs and behaviors (Dawson \& Prewitt, 1969). In addition, political socialization is a significant catalyst in building the identity of the younger generation, especially towards the formation of a superior nation-state (Odoemelam \& Aisien, 2013).

Some scholars stress that the process of political socialization is one of "unconscious social reproduction" (Guttman, 1987, p. 15). Political socialization is said to occur unconsciously in everyday life in this context. Mishra (1980) describes the process of political socialization that occurs without people realizing it, in which an individual accepts the applied norm without questioning its validity. Individuals are absorbed into the political culture, political orientation, and democratic system that they practise due to this process (Mishra, 1980). This learning process can take place in various settings, such as through the role of parents, peer influence, and other formal or informal influences. Another point made by Mishra (1980) is that through political socialization, an individual acquires political values in active political participation and before they are involved in political activity.

More specifically, the theory of political socialization outlines that several elements are applied in political socialization, namely knowledge, values and attitudes. Knowledge can influence the formation of values and attitudes individual, as well as knowledge can also be used to support and defend specific values and attitudes (Rush \& Althoff, 1971). At the same time, knowledge is also influenced by values and attitudes, primarily through information selection. On the other hand, attitudes are closely related to values where an individual's fundamental beliefs will play a significant role in determining their response to a stimulus and towards forming specific views or attitudes (Rush \& Althoff, 1971). In other words, attitudes may precede values and influence individual values. Knowledge, values and attitudes become contributors to an individual's experience, and conversely, the experience will also influence an individual's knowledge, values and attitudes (Rush \& Althoff, 1971). In addition, individual knowledge, values and attitudes will influence personality formation, and vice versa, unique personality will influence individual knowledge, values and attitudes (Rush \& Althoff, 1971). A person's character is very closely related to the experience he is going through, and at the same time, the experience can also influence the formation of personality. Hence, political socialization takes place from the reflection of a person's experiences, knowledge, values and attitudes, as well as the formation of an individual's personality. This process is closely related to every factor and agent an individual undergoes. 
That is why most studies on political socialization focus on the role of specific agents in nurturing, providing exposure and understanding of politically-related matters, particularly among the younger generation. This is because various agents carry out the political socialization in society such as family, school, mass media, peer groups (Claes et al., 2009; Fairbrother, 2002; Langton, 1969; McLeod, 2000; Merelman, 1980), religious institutions, social class and gender, as well as stakeholders and political parties (Almond, Powell, Dalton, \& Strom, 2008). Nevertheless, the learning process received by an individual through various agents in society will not bring an equivalent effect either within a system or between the systems (Rush \& Althoff, 1971). Moreover, a study on political socialization among youth in Malaysia was conducted by (Ismi et al., 2016). They investigated the current state of Malaysian youths' political socialization, factors related to political socialization, and how they can impact society, organizational leadership, and nation-building. Khalid and Wei (2016) studied contemporary electoral trends among Malaysian Chinese voters in the post-2008 General Election. Michael and Mun (2021) studied the role of political socialization on Facebook among Malaysian Chinese. In addition, NorHafizah et al (2021) focus a literature review on social media, youths and political participation in Malaysia. Despite the lack of particular studies, based on the literature review undertaken, it is clear that political socialization agents play a significant role among youth groups. No studies focus on the educated youths group in Malaysia, especially those comparing between Malays and Chinese. Thus, this paper examines the role of political socialization agents on Malaysian educated youths, focusing on students at Universiti Putra Malaysia (UPM). Accordingly, in discussing the development of political socialization among the youth groups being studied, this study emphasizes six main factors: family, peers, education, government, political parties, and mass media.

\section{Methodology}

This study implies a quantitative approach through survey techniques using self-administered questionnaires. The development of questionnaires is suitable for collecting and applying quantitative study designs of extensive sample data (Dawson, 2002; Saunders \& Fisher, 2006). The unit of analysis of this study is the youth which is consisted of students of Universiti Putra Malaysia (UPM), namely Malay and Chinese students only. The study has referred to the table presented by Cohen (1969), as well as Krejcie and Morgan (1970) in determining the sample size. Based on the table, it was suggested that if the population of the study was around 15,000 people, then the total sample to be taken was about 375 respondents. Therefore, to obtain the target number of 375 respondents, the researcher has distributed 450 sets of questionnaires.

The data collection technique in this study is through questionnaires and distributed through a non-probability approach which uses two main techniques, namely simple sampling approach and snowball sampling. The simple sampling approach is the most convenient and simple procedure in collecting data. As a result, the researcher has managed to get a total of 431 respondents. Out of 431 students, there are about 241 Malay and 190 Chinese students. To better correctly define the specific traits observed in a population, the approach in analysing research data for descriptive statistics has used IBM SPSS Statistics (SPSS) software.

As the respondents are only concentrated among UPM students, the findings of this study cannot explain the scenario of Malaysian youth as a whole. More precisely, the findings of 
this study can describe the scenario of political socialization of educated youths in general and explain the scenario of UPM students in particular. Similarly, the attention given to the Malay and Chinese students, the findings of this study are less precise in explaining the scenario of political socialization of youth from other ethnic groups in specific.

\section{Family Factor}

Family factors either form a good family institution or vice versa play a major role in providing exposure and socializing political values. This statement supports the arguments by Beck (1977); Dawson and Prewitt (1969); Hyman (1959) who argue that political socialization theory sees the family factor as acting as a major agent in the formation of political orientation. This is because the family especially the parents became the first authority to emerge in the life of an individual since childhood (Almond \& Verba, 1965). A child cannot be independent without the role and influence of his parents and family. The parent-child relationship in a family is hierarchical where each family unit is formed by at least two generations (Dawson \& Prewitt, 1969). The older generation is responsible for educating, advising, shaping and in turn influencing the younger generation. Hence, family factors are said to have strong socialization effects and have varying types of orientations in influencing the formation and self-development of an individual at different ages (Dawson \& Prewitt, 1969; Merelman, 1972).

Table 1: Family Factor as Agent of Political Socialization

\begin{tabular}{lcccc}
\hline \multicolumn{1}{c}{ Item } & \multicolumn{2}{c}{ Rarely } & \multicolumn{2}{c}{ Always } \\
& Malay (\%) & Chinese (\%) & Malay (\%) & $\begin{array}{c}\text { Chinese } \\
\text { (\%) }\end{array}$ \\
\hline $\begin{array}{l}\text { 1. Discuss current issues } \\
\text { 2. Parents educate on }\end{array}$ & 50.9 & 40.1 & 5 & 4 \\
$\quad \begin{array}{l}\text { political affairs } \\
\text { 3. Parents care }\end{array}$ & 10.9 & 18.1 & 45 & 26 \\
4. Pamily encouragement & 24.1 & 27.1 & 20 & 16.9 \\
\hline
\end{tabular}

Based on Table 1, the results reveal that $50.9 \%$ of the Malay respondents and $40.1 \%$ of the Chinese respondents were very rarely discussing current issues with their parents. The Malay $(45 \%)$ and Chinese (26\%) parents continue to play an important role in providing education about political affairs to their children. Although the parents have a role in educating their children on political affairs, they are less concerned about their children's political beliefs. This is proven that $36 \%$ of the Malay youths and $27.1 \%$ of Chinese youth stated that their parents do not care about their political affiliation. In the meantime, there is about $31.8 \%$ of Malay youth and $18.6 \%$ of Chinese youth said that their parents always encourage them to trigger the political developments in the country. Therefore, the results of this study show the existence of variations in the role of parents in socializing their children about political affairs. The study also found that parents of the Malay youths are more influential in the process of political socialization of their children compared to the role played by parents of the Chinese youths.

Most studies that explore the role of the family especially parents in the process of political socialization found that the family has a very significant relationship in influencing the formation of the political orientation of an individual at different ages. Thomas (1990) who 
studied political socialization among high school students in Oklahoma City, Japan found that families especially the parents have a considerable influence in building political awareness. Thomas found that a student would have extensive knowledge if they were exposed to political discussions with family members. The same thing happened among the Malay youths but was rarely found among the Chinese youth.

\section{Peer Factor}

Peers are a fundamental form of social relationships that act as an important instrument for the process of social learning and adjustment in all ages of society (Dawson, 1969). Peers bring various forms of influence, either positively or negatively, towards their peers. They develop influence through the sharing of information, advice and views, employing dialogue, persuasion or even coercion. The influence of peers in the process of political socialization differs from one culture to another (Dawson \& Prewitt, 1969). However, in the context of this modern world, the influence of peers is seen to be strong enough in determining an individual's political orientation. The influence of peers complements the influence of family especially in today's complex society (Dawson \& Prewitt, 1969). Dawson and Prewitt (1969) also asserted that forms of relationships that exist outside of family ties play an important role in providing, motivating and shaping individual perceptions in society. Relationships with these peers also depend on the patterns of interaction that exist between them. The more frequent the interaction between the peers, the more the influence will be received.

Table 2: Peer Factor as Agent of Political Socialization

\begin{tabular}{lcccc}
\multicolumn{1}{c}{ Item } & \multicolumn{2}{c}{ Rarely } & \multicolumn{2}{c}{ Always } \\
& Malays (\%) & Chinese (\%) & Malays (\%) & $\begin{array}{c}\text { Chinese } \\
\text { (\%) }\end{array}$ \\
\hline $\begin{array}{l}\text { 1. Discuss current issues } \\
\text { 2. Share current }\end{array}$ & 22.7 & 23.4 & 33.2 & 20.6 \\
$\begin{array}{l}\text { developments } \\
\text { 3. Clarification of current }\end{array}$ & 25.5 & 25.5 & 30.4 & 18.6 \\
$\begin{array}{l}\text { issues } \\
\text { 4he influence of }\end{array}$ & 25.1 & 26.9 & 30.9 & 17.2 \\
$\quad$ political partners & 43.2 & 34.6 & 12.8 & 9.5 \\
\hline
\end{tabular}

According to Table 2, the results showed that $33.2 \%$ of Malay youths and $20.6 \%$ of Chinese youths always talk about current issues with their friends. Similarly, about $30.4 \%$ of Malay youth are always sharing the current issues in the country with their partners compared with $25.5 \%$ of the Chinese youth who rarely share the current issues with their peers. $30.9 \%$ of the Malay peers always provide a clarification of the current issues prevailing in the country at and $17.2 \%$ of Chinese youth are rarely doing so. Both Malay $(43.2 \%)$ and Chinese $(34.6 \%)$ respondents were less influenced by the political affiliation of their peers. The study found that Malay youths receive more influence from peers compared to Chinese youths. However, they do not simply follow and accept the political ideology of their peers.

Peers become the priority and importance during adolescence and continue to have a significant influence on adulthood (Dawson, 1969). Thus, peers become important socializing agents at the adolescent level (Harvey, 1972; Parsons, 1959; Riesman et al., 1950) typically during the secondary school period (Parsons, 1959) and at the college level or prestigious 
group (Langton, 1969). If the relationship between the peers has a strong attraction, high resilience and a precise understanding between them, then the relationship can be a lasting bond until adulthood. In the meantime, the bond that exists is also influenced by the forms of relationships between them such as spouses, schoolmates, workplace colleagues, neighborhood partners, voluntary associations and so forth (Silbiger, 1977). The most important is the extent to which the relationship influences the political orientation of the individual. Most scholars agree that there are two basic conditions of how peers influence their friends in the context of political socialization. First, there must be communication about political affairs and second, there must be elements of acceptance that bind them (Beck, 1977; Harvey, 1972; Tedin, 1980 ). In the context of the respondents, there is the extent of acceptance of peer political influence which depends on the interactions and communication that occur between them but does not occur in the context of the elements of acceptance that bind them (Ismail et al., 2016). This is evident where only a small number of Malay and Chinese youth are affected by the political affiliation of their peers.

\section{Education Factor}

The education factor is a medium of political socialization that is quite important for children, adolescents and youth. In this context, schools and learning institutions are seen as major agents of political socialization. This is because it is directly or indirectly involved in the process of raising an individual from childhood until the person grows into adolescence and adulthood. According to Dawson and Prewitt (1969), from early childhood to late adolescence is the largest part of an individual to be exposed to and learn certain skills and values. Systematic tutoring is used as a tool and the necessary social skills are revealed at that age in preparation for adulthood. Such instruction may be in the hands of the teacher, parents, or older siblings (Dawsen \& Prewitt, 1969). Nevertheless, schools are seen as key agents in providing formal guidance on basic matters such as cultural norms, various ritual activities and the importance of community involvement.

Schools play many roles in shaping an individual's political perceptions and orientation. This development continues when an individual pursues his studies to a higher level where the public or private higher learning institutions become one of the important agents of political socialization in the development of students' political orientation. The level and degree of education received by a person become determinant to the process of political socialization (Brown, 1996). In other words, special education such as schools and learning institutions play an important role in the social and political development of an individual. This is proven in the studies by (Almond and Verba, 1965; Downey et al., 2004; Easton and Hess, 1962; Glasberg and Shannon, 2011; Hess and Torney, 1967; Jennings and Niemi, 1973; Langton and Jennings, 1968). 
Table 3: Education Factor as Agent of Political Socialization

\begin{tabular}{|c|c|c|c|c|}
\hline \multirow[t]{2}{*}{ Item } & \multicolumn{2}{|c|}{ Rarely } & \multicolumn{2}{|c|}{ Always } \\
\hline & Malays (\%) & Chinese (\%) & Malays (\%) & $\begin{array}{l}\text { Chinese } \\
\text { (\%) }\end{array}$ \\
\hline $\begin{array}{l}\text { 1. Lecturers/teachers give } \\
\text { exposure }\end{array}$ & 19 & 22 & 36.9 & 22 \\
\hline $\begin{array}{l}\text { 2. Exposure in school / } \\
\text { university }\end{array}$ & 13.5 & 18.3 & 42.5 & 25.8 \\
\hline 3. Apply national spirit & 13.5 & 19 & 42.5 & 25.1 \\
\hline $\begin{array}{l}\text { 4. Influence the political } \\
\text { ideology }\end{array}$ & 41.1 & 31.8 & 14.8 & 12.3 \\
\hline
\end{tabular}

Based on Table 3, the results showed that $36.9 \%$ of Malay youth and $22 \%$ of Chinese youths stated that their lecturers or teachers always give exposure and discuss current issues within and outside the country. At the same time, about $42.5 \%$ of Malay youth and $25.8 \%$ of Chinese youth got a lot of exposure to current political affairs in schools and universities. Similarly, $42.5 \%$ of the Malay youths and $25.1 \%$ of the Chinese youths stated that the role of schools and universities apply a lot to the national spirit. However, $41.1 \%$ and $31.8 \%$ of Malay and Chinese youths supported that the lecturers and teachers rarely affect the political ideology. Hence this study found that educational institutions have a significant role in the process of political socialization of youths, especially in providing exposure to current political developments and the application of the national spirit (Ismail, 2015). However, the teaching staff in educational institutions did not greatly influence the political beliefs of the respondents.

\section{Government Factor}

Government factors play a role in driving political socialization among its people. In this case, the government is the main source of all forms of information that will be disseminated to the public (Glasberg \& Shannon, 2011). The government, at any level, is responsible for providing information to the media based on their interests. The government usually uses the mass media as a communication medium to spread their propaganda to influence public perception (Glasberg \& Shannon, 2011). If the propaganda spread by the media does not bring any expected effect, the government may change tactics by appealing to the people to be more patriotic to gain support for the interests of the upper classes (Glasberg \& Shannon, 2011) and maintain their status quo. However, if such a process of political socialization is not effective, Glasberg and Shannon (2011) pointed out that the government may take force action by using the police or the army. For example, in China in 1991, the government used military force to restrict student democratic movements (Glasberg \& Shannon, 2011). The government is always seen to play a role in driving the formation of individual perspectives, especially in the application of values and norms required in the political development of the country. In other words, the government plays an important role in delivering a lesson in a formal form (Mortimer \& Simmons, 1978). In addition, the government also has a great influence in the socialization process to determine the role of the state in the future (Mortimer \& Simmons, 1978). 
Table 4: Government Factor as Agent of Political Socialization

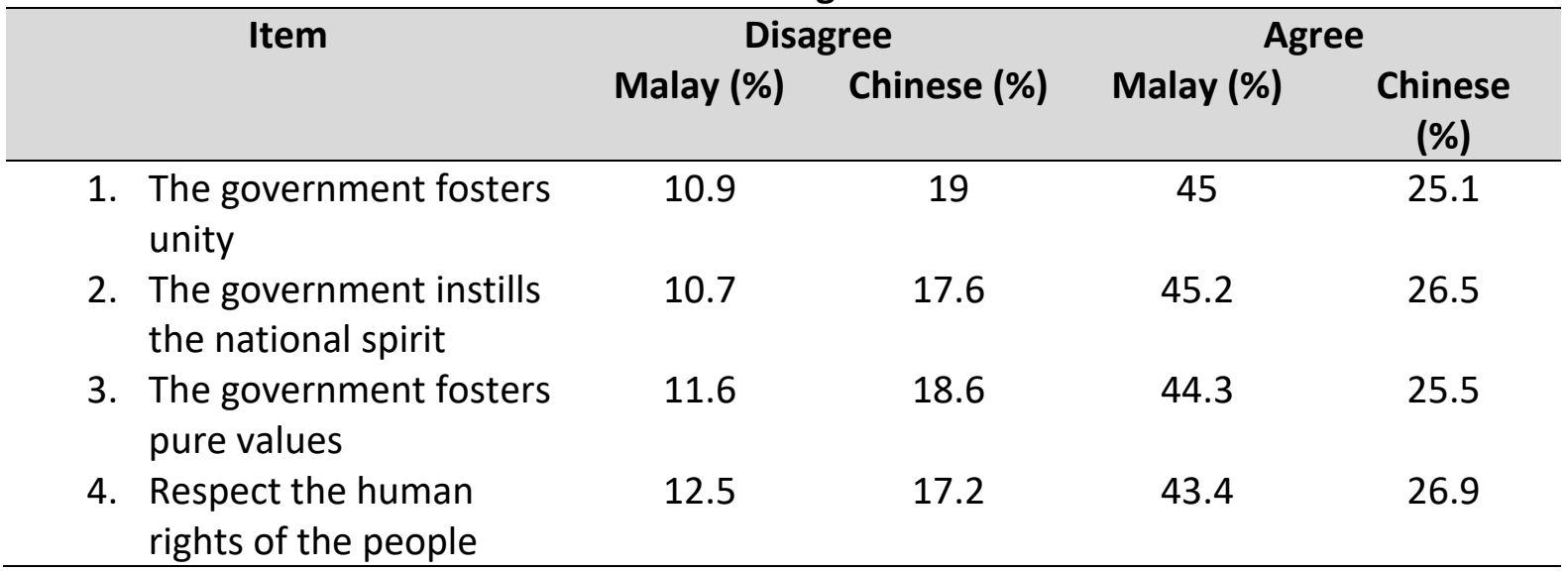

Based on Table 4, the results showed that the government carries considerable influence in the process of political socialization among the Malay youths, particularly in the aspect of fostering unity (45\%), implementing the national spirit (45.2\%), fostering the values $(44.3 \%)$ and respecting for the human rights (43.4\%). The same items were also agreed by the Chinese youths but at a smaller rate, namely, efforts to foster unity $(25.1 \%)$, to inculcate the national spirit (26.5\%), to cultivate noble values $(25.5 \%)$ and to respect for human rights $(26.9 \%)$. The findings prove that the government has significant implications in shaping and forming the political socialization of the youth. Various approaches have been taken by the government in ensuring that its aspirations and goals are achieved. In addition, the government also plays a key role in the political socialization process through the introduction and implementation of various forms of initiatives, campaigns, policies, acts and laws. At the same time, various forms of programs are also implemented such as the National Service Training Program (PLKN) in the framework for youth development with various goals that have been targeted. Such programs can bring a more effective impact on political socialization (Youniss, 2005).

\section{Political Party Factor}

Political party factors are one of the important agents in the process of political socialization especially in modern democratic systems (Odoemelam \& Aisien, 2013). According to Odoemelam and Aisien (2013), a political party can be defined as;

"An organized group of citizens of a state with similar views, ideas and ideology which they consider to be fundamental to the political system and good governance. The main purpose of a political party is to contest elective political offices with a view to form government" (Odoemelam \& Aisien, 2013, p. 239).

Political parties play an important role in the process of political indoctrination of the people. They are the most active and direct agents in the process of political socialization. Their role can be seen especially during the election period where the political parties serve as agents who drive voters and as political teachers to young people through talks, posters, pamphlets, slogans, marches, propaganda, banner, badges, door to door campaigns and the activity of soliciting votes in the public society (Mishra, 1980). In all these activities, young people participate with curiosity and thus they are politicized smoothly (Mishra, 1980). In addition, political parties through their propaganda provide various forms of alternatives, cast various 
ideas and views, highlight various issues of the people, criticize the government leaders and invite the people to make judgments, while rationalizing their demands to seize power (Mishra, 1980; Ofoeze, 2001). Through this process, they enlarge the cognitive map of individuals and enable them to form a clearer understanding of political systems and cultures (Mishra, 1980).

Table 5: Political Party Factor as Agent of Political Socialization

\begin{tabular}{lcccc}
\hline \multicolumn{1}{c}{ Item } & \multicolumn{2}{c}{ Rarely } & \multicolumn{2}{c}{ Always } \\
& Malay (\%) & Chinese (\%) & Malay (\%) & $\begin{array}{c}\text { Chinese } \\
\text { (\%) }\end{array}$ \\
\hline 1. $\begin{array}{l}\text { Listen to the political } \\
\text { speech/talk }\end{array}$ & 50.1 & 41.3 & 5.8 & 2.8 \\
$\begin{array}{l}\text { 2. } \begin{array}{l}\text { Read the leaflet by the } \\
\text { political parties }\end{array} \\
\begin{array}{l}\text { Follow the progress of } \\
\text { the political party }\end{array}\end{array}$ & 45.5 & 38.3 & 10.4 & 5.8 \\
$\begin{array}{l}\text { 4. Read the political party } \\
\text { website }\end{array}$ & 44.8 & 37.8 & 11.1 & 6.3 \\
\hline
\end{tabular}

Table 5 shows the political parties do not take a great influence on the development of political socialization among the Malay and Chinese youths. This is evident where $50.1 \%$ of Malay youths and $41.3 \%$ of Chinese youths rarely hear political speeches. In addition, $45.5 \%$ of Malay youths and $38.3 \%$ of the Chinese youths are rarely read the leaflet issue by the political parties. Similarly, $44.8 \%$ of Malay youths and $37.8 \%$ of Chinese youths only occasionally follow the progress of political parties. $44.3 \%$ of the Malay youths and $37.1 \%$ of Chinese youths are found to rarely open and read political party websites. Therefore, through the findings, we can see that these educated youths are less concerned about political parties perhaps due to the educational burden or the existence of certain limitations to involve in political parties. This situation also shows that political parties in Malaysia fail to function effectively to be directly involved in the process of political socialization of youth (Ismail, 2015). Probably, this is because the approach practiced was not reach properly to the target group.

\section{Mass Media Factor}

In today's era of technology, mass media is one of the important mediums in the process of political socialization. This is because the mass media plays a very effective role in disseminating information and messages that can affect the political orientation of an individual. This development covers all aspects of mass media whether electronic media or print media such as newspapers, television, radio, magazines, the internet and various other communication media. Dawson and Prewitt (1969); Glasberg and Shannon (2011) asserted that in modern society, the mass media becomes a fairly effective medium as an agent of political socialization in disseminating information. In addition, the mass media is also said to be an important agent in fostering national spirit (Frey, 1968). A study conducted by Garramone and Atkin (1986) on the effects of exposure to media news for four media categories namely television, radio, newspapers and magazines on political knowledge and political behavior found that there was a significant relationship between exposure to media news with political knowledge and behavior. Moreover, exposure to electronic media has a 
significant correlation to political knowledge compared to exposure to print media (Garramone \& Atkin, 1986). At the same time, the impact of the latest and sophisticated technology as well as the weaknesses in traditional social structures such as the family has made the mass media an important factor in the development of political orientation (Dawson \& Prewitt, 1969). For instance, through the mass media, children are not only gain information through what they read, watch and hear. They are also easily influenced by the views, attitudes and behaviors displayed in the mass media (Conway ET AL., 1981).

Table 6: Mass Media Factor as Agent of Political Socialization

\begin{tabular}{llcccc}
\hline \multicolumn{1}{c}{ Item } & \multicolumn{2}{c}{ Rarely } & \multicolumn{2}{c}{ Always } \\
& Malay (\%) & Chinese (\%) & Malay (\%) & $\begin{array}{c}\text { Chinese } \\
\text { (\%) }\end{array}$ \\
\hline 1. Read the newspaper & 31.1 & 21.8 & 24.8 & 22.3 \\
2. Watch the news & 35.3 & 27.6 & 20.6 & 16.5 \\
3. Listen to the radio & 33.4 & 29.9 & 22.5 & 14.2 \\
4. Surf the internet & 19 & 20.9 & 36.9 & 23.2 \\
\hline
\end{tabular}

Based on Table 6, the results reveal that the mass media has an influence on the development of political socialization of the youth groups but the influence is not large. About $31.1 \%$ of Malay youth and $21.8 \%$ of Chinese youth are rarely read the newspapers to update the current political developments taking place in the country. Similarly, 35.3\% of Malay youths and $27.6 \%$ of Chinese youth are rarely watching the news just to keep abreast of political developments and current issues prevailing in the country. In addition, 33.4\% of Malay youths and $29.9 \%$ of Chinese youth also rarely listen to the radio to find out about current issues. However, $36.9 \%$ of Malay youths and $23.2 \%$ of Chinese youths surf the internet to seek information about current issues in Malaysia. The study found that youths do not use the mainstream channels namely, television and radio to update political developments and current issues but more rely on internet resources. This is because the learning environment which is less conducive for them to get newspaper resources, watch television or listen to the radio. In addition, with the sophistication of technology, they now prefer to use more effective social media mediums (Ismail, 2015).

\section{Discussion: The Influence of Political Socialization}

This study found that family factors have their role in influencing the process of political socialization among the respondents. This can be seen in the context of parents who still play an important role in educating their children on political affairs. Nevertheless, family factors in socializing an individual (their children) will become less influential when other important institutions (primary and secondary) participate in the socialization process (Dawson \& Prewitt, 1969; Jennings \& Niemi, 1973; Merelman, 1972). In this situation, when families fail to nurture their children with a political orientation in addition to the existence of other institutions, then those other institutions are likely to become more influential (Dawson \& Prewitt, 1969). According to Dawson and Prewitt (1969), in a society without secondary institutions, the family institution is likely to be more monopolistic in the process of political socialization. However, the role of the family as an agent of political socialization becomes less influential when there are other institutions such as schools and the influence of peers. Schools are seen as major competitors as agents of political socialization in societies in developed countries (Dawson \& Prewitt, 1969). 
This study reveals that youths more often discuss current issues and political developments in the country with their peers, especially among the Malay youth groups. Tedin (1980) explained that adolescents are much closer to their peers than to parents. However, such a view contradicts Geary's (1996) findings who found that although the previous researchers perceived youths as more dependent on peers and less dependent on their parents in many situations, such freedom would not lasting across all forms of social relationships. Parents do indeed encourage independent thinking with peers and the development of behaviors nurtured by them, and such behaviors will influence relationships with peers (Geary, 1996).

In addition, this study found that education factors play an important role in the development process of political socialization among the respondents. This supports the findings by Messick (1970) through his study that learning institutions become an influential agent of political socialization compared to other agents in disseminating various sources of information on political affairs. Downey et al (2004); White et al (2008) argue that schools play an important role in creating a balance between children from disadvantaged backgrounds with children who are more advantaged in political knowledge and adopting a dominant political culture in society. This proves that learning institutions have a great influence in determining the development of individual political socialization.

The important role of educational institutions in the process of political socialization is widespread. This is supported by the study of Easton and Hess (1962) who explained that the longer an individual studies in school or higher learning institutions, the more knowledge he acquires and this development will lead to the existence of political consciousness. Easton and Hess (1962) also pointed out that an individual of three years old has begun to learn political affairs in school and their knowledge will become more solid by the age of seven. This finding is in line with the results of the study by Almond and Verba (1965) who argued that when an individual gets higher education, then it will lead to higher political awareness and state affairs. In addition, higher levels of education will drive individuals' stronger understanding of the political arena, causing them to feel more confident in political skills and increase interest in political affairs (Brown, 1996). In addition, at the level of higher education institutions, university lecturers will generally provide a broader and in-depth exposure to a political issue as well as examine current political developments that occur in and outside the country in more detail.

This study also found that the government has a significant contribution in influencing the process of political socialization of the respondents. Through various approaches and programs implemented, the government has succeeded in inculcating elements of unity, national spirit, noble values and showing that they respect the human rights of the people. PLKN is not the only program that emphasis these elements but also various other programs such as Rakan Muda, IM4U, RELA Youth Squad, Crime Awareness Team (CAT), Premier Youth Award, MyCorps and so forth (Mamat, 2013). The approach taken is in line with the national goals and policies which are moving towards the formation of a Malaysian nation. At the same time, this action is in line with the government's initiative which targets the development of youth holistically in preparation for the era of a developed country.

This study found that political parties did not bring influence in the process of political socialization of the respondents. Although political parties serve as important agents who 
fight for political ideology, interests of the people, build the political culture of society, develop political education and recruit political leadership (Odoemelam \& Aisien, 2013), but it does not imply effectiveness among educated youths in UPM. In developed societies such as the United States and Britain, political parties play a key role as agents of political socialization particularly in promoting positive orientations that generate norms, values, beliefs and attitudes that support the systems of political power, promote national integration and nation building (Odoemelam \& Aisien, 2013 ). Political parties play a role in nurturing their society with the core values of national politics, beliefs and norms of society to support the formation of a nation-state (Ofoeze, 2001). In addition, political parties in the United States and Britain also play a role in supporting the development of sociopolitics, economic institutions, structures and symbols of its society (Ofoeze, 2001).

In the context of mass media, the results show that mass media has an influence on the development of political socialization of the respondents but the influence is not large due to certain limitations. The study of Chaffee et al (1977) on the influence of mass media in the process of political socialization have formulated some findings as follows; (i) the mass media is the basic source of political knowledge among the youth; (ii) the dominant mass media in political learning are newspapers and television which have varying influence based on age and socioeconomic status; (iii) the influence of the mass media on the youth is more to a political opinion other than sources of information; (iv) political differences between generations also exist through the influence of mass media where the younger generation does not rely on the news given by their parents. Moreover, the study of Glasberg and Shannon (2011) in the United States found that the mass media carries varying influences on political orientation based on gender depending on the personality featured in television and so forth. These findings contradict the findings of Conway et al (1981) who found that mass media factors did not carry a different influence in terms of gender.

\section{Conclusion}

The development and political orientation of the younger generation, particularly the educated youth in a country should be driven from an early age. They are the prospects of the country. In this regard, the learning process about the political affairs of these youth groups is very important to be studied to understand which factors and agents bring great influence in the formation of their political literacy and awareness. Based on the results, the family factor still has its role in the process of youth political socialization. Similarly, peer factors are seen to play an important role in the learning environment at UPM, which is quite far away from their families. Education factors and government factors were found to carry the most significant influence on the learning process of the respondents. The political parties did not bring effective influence on both the Malays and Chinese youths. Meanwhile, the mass media factor has a relatively limited influence as the learning environment is relatively limited for UPM students to access certain channels easily. Therefore, every significant factor and agent in the process of political socialization of youths needs to increase their role to enhance the impact of political literacy and awareness on today's younger and future generations which are increasingly dynamic.

\section{Acknowledgement}

Acknowledgement is given to the "Geran Putra GP/2017/9582600" for the project entitled "Persepsi Belia (Mahasiswa Universiti Awam) Terhadap Malaysia Baharu" (Youth Perceptions 
[Public University Students] Towards New Malaysia) from the Universiti Putra Malaysia (UPM), which contributed to the publication of this article.

\section{Notes}

This article was published as a chapter in book in the Malay version. Reference to the original article as follows: Mohd Mahadee Ismail. (2019). The Influence of Political Socialization among the Young Generation in Malaysia: A Study on Universiti Putra Malaysia Students. In Mohd Mahadee Ismail (Edt.). Politics, Ethnicity and Civilization: The Dynamics of Society. Universiti Putra Malaysia Publisher.

\section{References}

Abdullah, N. H., Hassan, I., Ahmad, M. F., Hassan, N. A., \& Ismail, M. M. (2021). Social media, youths and political participation in Malaysia: A review of literature. International Journal of Academic Research in Business and Social Sciences (HRMARS), 11(4), 845 - 857. https://doi.org/10.6007/IJARBSS/v11-i4/9578

Almond, G. A., \& Coleman, J. S. (1960). The politics of the developing areas. New Jersey, United States, :Princeton University Press.

Almond, G. A., \& Verba, S. (1965). The civic culture: Political attitudes and democracy in five nations. Boston, MA: Little, Brown and Company.

Almond, G. A., Powell, G. B., Dalton, R. J. \& Strom, K. (2008). Comparative politics today: A world view (9th ed.). New York: Pearson-Longman.

Beck, P. A. (1977). The role of agents in political socialization. In Renshon, S. A. (Edt.). Handbook of political socialization: Theory and research. Pp. 115-141. New York: The Free Press.

Brown, S. G. (1996). Incorporating political socialization theory into baccalaureate nursing education. Nurs Outlook, 44(3), 120-123. https://doi.org/10.1016/S00296554(06)80003-5

Chaffee, S. H., Jackson-Beeck, M., Durall, J. \& Wilson, D. (1977). In Renshon, S. A. (Edt.). Handbook of political socialization: Theory and research. Pp. 223-258. New York: The Free Press.

Claes, E., Hooghe, M., \& Stolle, D. (2009). The political socialization of adolescents in Canada: Differential effects of civic education on visible minorities. Canadian Journal of Political Science, 42(3), 613-636. https://doi.org/10.1017/S0008423909990400

Cohen, J. (1969). Statistical power analysis for the behavioral sciences. Academic Press.

Cohen, R., \& Kennedy, P. (2007). Global sociology. Palgrave MacMillan.

Conway, M. M., Wyckoff, M. L., Feldbaum, E., \& Ahern, D. (1981). The news media in children's political socialization. The Public Opinion Quarterly, 45(2), 164-178.

Dawson, C. (2002). Practical research methods: A user-friendly guide to mastering research techniques and projects. Oxford: How to Books Ltd.

Dawson, R. E. \& Prewitt, K. (1969). Political socialization. Boston: Little, Brown \& Co.

Downey, D., Hippel, P. V., \& Broh, B. (2004). Are school the great equalizer? Cognitive inequality during the summer months and the school year. American Sociological Review, 69(5), 613-635. https://doi.org/10.1177/000312240406900501

Easton, D., \& Hess, R. D. (1962). The child's political world. Midwest Journal of Political Science, 11(3), 229-246. https://doi.org/10.2307/2108634

Easton, D. (1968). The theoretical relevance of political socialization. Canadian Journal of Political Science, 1(2): 125-146. https://doi.org/10.1017/S0008423900036477 
Fairbrother, G. P. (2002). Political socialization and critical thinking: Their influence on Hong Kong and mainland Chinese university students' attitudes toward the nation [Unpublished doctoral dissertation]. The University of Hong Kong.

Frey, F. W. (1968). Socialization to national identification among Turkish peasants. The Journal of Politics, 30(4), 934-965. https://doi.org/10.2307/2128683

Garramone, G. M., \& Atkin, C. K. (1986). Mass communication and political socialization: Specifying the effects. The Public Opinion Quarterly, 50(1), 76-86.

https://doi.org/10.1086/268960

Geary, C. A. (1996). Adolescent autonomy with parents as a predictor of low susceptibility to peer pressure [Unpublished master thesis]. University of Virginia.

Glasberg, D. S., \& Shannon, D. (2011). Political sociology: Oppression, resistance and the state. Los Angeles: Sage Publication.

Greenstein, F. (1960). The benevolent leader: Children's images of political authority. American Political Science Review, 54(4), 934-943. https://doi.org/10.1017/S0003055400122269

Harvey, T. G. (1972). Computer simulation of peer group influences on adolescent political behavior: An exploratory study. Midwest Journal of Political Science, 16(4), 570-602.

Hess, R., \& Easton, D. (1960). The child's changing image of the president. Public Opinion Quarterly, 24(4), 632-644. https://doi.org/10.1086/266978

Hess, R., \& Torney, J. (1967). The development of political attitudes in children. Chicago: Aldine Press.

Hyman, H. (1959). Political socialization: A study in the psychology of political behavior. New York: The Free Press.

Ismail, I. A., Dahalan, D., Zawawi, D., Abdullah, H., \& Yusof, W. M. (2016). Political socialization of Malaysian youth: The present state and the way forward [Conference presentation]. In International Conference on Youth (ICYOUTH) 2016, 15-17 Nov. 2016, Mines Wellness Hotel, Seri Kembangan, Selangor.

Ismail, M. M. (2015). Political socialization, national ethos and nation-states: The study of civic education and National Service Training Program (PLKN) among Universiti Putra Malaysia (UPM) Students [Unpublished doctoral dissertation]. Universiti Kebangsaan Malaysia.

Ismail, M. M., Hassan, N. A., Abdullah, A., Othman, Z., Yunus, M. M., \& Din, M. H. A. (2021). National ethos formation of Malaysian youth: Medium for building a nation state. Akademika 91(1), 3-14. https://doi.org/10.17576/akad-2021-9101-01

Ismail, M. M., Noor, M. M., \& Othman, Z. (2016). National Service Training Program (PLKN): A new platform for political socialization. Research Journal of Social Sciences, 9(3), 2836.

Jennings, M. K., \& Niemi, R. G. (1973). The transmission of political values from parent to child. In Dennis, J. (Edt.). Socialization to politics. Canada: John Wiley \& Sons Inc.

Khalid, K. M., \& Wei, J. L. S. (2016). Contemporary electoral trends among Malaysian Chinese voters: Changing political socialisation and orientation in the post 2008 General Election. European Journal of East Asian Studies, 15(2), 174-208. https://doi.org/10.1163/15700615-01502007

Krejcie, R. V., \& Morgan, D. W. (1970). Determining sample size for research activities. Educational and Psychological Measurement, 30, 607-610. https://doi.org/10.1177/001316447003000308 
Langton, K., \& Jennings, M. K. (1968). Political socialization and the high school civic curriculum. American Political Science Review, 62(3), 862-867.

https://doi.org/10.2307/1953435

Langton, K. P. (1969). Political socialisation. New York: Oxford University Press.

Mamat, S. (2013). Volunteers: My beautiful Malaysia day 2013. Institute for Youth Research Malaysia Bulletin (1st ed.). Putrajaya: Ministry of Youth and Sports Malaysia.

Marshall, G. (1996). The concise oxford dictionary of sociology. Oxford: Oxford University Press.

McLeod, J. M. (2000). Media and civic socialization of youth. Journal of Adolescent Health, 27(2), 45-51. https://doi.org/10.1016/S1054-139X(00)00131-2

Merelman, R. M. (1969). The development of political ideology: A framework for the analysis of political socialization. The American Political Science Review, 63(3), 750-767.

Merelman, R. M. (1972). The adolescence of political socialization. Sociology of Education, 45(2), 134-166. https://doi.org/10.2307/2112005

Merelman, R. M. (1980). The family and political socialization: Toward a theory of exchange. The Journal of Politics, 42(2), 461-486.

Messick, R. G. (1970). Political awareness among Mexican-American high school students. High School Journal, 54, 108-110.

Michael, E., \& Mun, C. Y. (2021). The role of political socialization on Facebook among Malaysian Chinese. International Journal of Politics, Publics Policy and Social Works, 3(9), 01-08. https://doi.org/10.35631/IJPPSW.39001

Mishra, S. N. (1980). Agencies of political socialization: A study in political parties (A case study of Amarpur Gram Panchayat). The Indian Journal of Political Science, 41(1), 115-121.

Mortimer, J. T., \& Simmons, R. G. (1978). Adult socialization. Annual Review of Sociology, 4, 421-454. https://doi.org/10.1146/annurev.so.04.080178.002225

Neundorf, A., \& Smets, K. (2017). Political socialization and the making of citizens. Oxford Handbooks Online. Oxford University Press. https://doi.org/10.1093/oxfordhb/9780199935307.013.98

Odoemelam, U. B., \& Aisien, E. (2013). Political socialization and nation building: The case of Nigeria. European Scientific Journal, 9(11), 237-253. https://doi.org/10.19044/esj.2013.v9n11p\%25p

Ofoeze, H. G. A. (2001). Political parties and pressure groups. Willy Rose and Appleseed Publishing.

Parson, T. (1959). The school class as a social system: Some of its function in American society. Harvard Education Review, 29(4), 297-318.

Pye, L. W. (1959). Political modernization and research on the process of political socialization. Social Science Research Council Items, 13(3), 236-241.

Roberts, S. (1971). Socialization of support for political authority in Britain: A long-term view. British Journal of Political Science, 1, 121-128.

Rush, M., \& Althoff, P. (1971). An introduction to political sociology. Melbourne: Thomas Nelson and Sons Ltd.

Saunders, K. J., \& Fisher, D. L. (2006). An action research approach with primary pre-service teachers to improve university and primary school classroom environments. In Fisher, D. L. \& Khine, M. S. (Eds.). Contemporary Approaches to Research on Learning Environments. Pp. 247-272. Singapore: World Scientific.

Sigel, R. (1970). Assumptions about the learning of political values. In Greenberg, E. S. (Edt.). Political socialization. Pp. 19-23. New York: Atherton Press. 
Silbiger, S. L. (1977). Peer and political socialization. In Renshon, S. A. (Edt.). Handbook of political socialization: Theory and pesearch. Pp. 172-189. The Free Press.

Tedin, K. L. (1980). Assessing peer and parent influence on adolescent political attitudes. American Journal of Political Science, 24(1), 136-154.

Thomas, R. (1990). Applying a patriotism textbook-rating device: An Indonesian example. Educational Research Quarterly, 12, 46-52.

White, S., Nevitte, N., Blais, A., Gidengil, E., \& Fournier, P. (2008). The political resocialization of immigrants: Resistance or lifelong learning? Political Research Quarterly, 61(2), 268281. https://doi.org/10.1177/1065912908314713

Youniss, J. (2005). Much to learn about new agents of political socialization. Human Development, 48, 356-362. https://doi.org/10.1159/000088253 